\title{
BIMBINGAN TEKNIS DASAR-DASAR PROSES PEMBUATAN KOMPONEN SEPATU REM SEPEDA MOTOR DENGAN MODEL HIGH PRESSURE DIE CASTING BERBAHAN SKRAP ALUMINIUM BAGI IKM LOGAM DISPERINDAG KABUPATEN MALANG
}

\author{
Djoko Andrijono $^{1)}$, Sufiyanto ${ }^{2)}$ \\ ${ }^{1,2)}$ Fakultas Teknik, Universitas Merdeka Malang \\ 1) Email: djoko.andrijono@unmer.ac.id, ${ }^{2)}$ sufiyanto@unmer.ac.id
}

\begin{abstract}
Abstrak
Sepatu rem merupakan elemen mesin menyatu dengan kampas rem yang terpasang di dalam tromol. Saat dilakukan pengereman timbul gesekan antara permukaan kampas rem dengan dinding bagian dalam tromol, sehingga menimbulkan keausan pada kampas rem, akibatnya diperlukan penggantian kampas rem termasuk sepatu rem. Jumlah penduduk Indonesia tahun 2018 mencapai 260 juta dan kepemilikan sepeda motor mencapai 137,7 juta artinya jumlah sepeda motor tersebut, sudah mencapai separuh dari jumlah penduduk Indonesia, sehingga kebutuhan sepatu rem sangat dituntut tersedia dipasaran, karena kampas rem yang sudah aus harus diganti. Kondisi tersebut, memberi peluang bisnis bagi para IKM logam untuk mendirikan industri pengecoran, khususnya di bidang pembuatan sepatu rem. Dipilihnya proses pengecoran tersebut, karena proses pengecoran dapat digunakan untuk proses remelting dan mampu memproduksi dengan geometri produk cor yang rumit dan kompleks serta dapat digunakan untuk produksi massal. Bahan dasar sepatu rem dapat memanfaatkan limbah logam bukan besi jenis skrap aluminium yang memiliki sifat dapat dilebur kembali dan salah satu cara untuk memperoleh produk sepatu rem secara massal tanpa diperlukan proses pengerjaan lanjut dapat menggunakan proses pengecoran jenis HDPC, karena HDPC menggunakan cetakan yang memiliki tingkat kepresisian yang tinggi dan proses pencetakannya dapat dilakukan secara berulang-ulang dengan bentuk dan ukuran produk yang sama.
\end{abstract}

Kata Kunci: HPDC, Sepatu Rem, Skrap Aluminium

\section{PENDAHULUAN}

a. Analisis Situasi

Wilayah Kabupaten Malang memiliki luas $3.534,86 \mathrm{~km}^{2}$ atau 353.486 ha dan terletak pada koordinat $112^{\circ} 17^{\prime} 10,90^{\prime \prime}$ - 122 $2^{\circ} 57^{\prime} 00,00^{\prime \prime}$ Bujur Timur, 744'55,11" - 8²6’35,45" Lintang Selatan. Kabupaten Malang merupakan daerah dengan luas wilayah terbesar kedua di Jawa Timur setelah Kabupaten Banyuwangi. Berdasarkan luas Kabupaten Malang tersebut, terbagi atas kawasan daratan dan lautan, masing-masing seluas $3.534,86$ $\mathrm{km}^{2}$ dan $557,81 \mathrm{~km}^{2}$.

Batas wilayah Kabupaten Malang sebagai berikut: Sebelah Utara: Kabupaten Jombang, Kabupaten Mojokerto, Kabupaten Pasuruan dan Kabupaten Probolinggo Sebelah Timur: Kabupaten Lumajang. Sebelah Selatan: Samudera Indonesia. Sebelah Barat: Kabupaten Blitar dan Kabupaten Kediri Bagian Tengah (Lingkar Dalam): Kota Malang dan Kota Batu.

Secara administratif kewilayahan, Kabupaten Malang terdiri dari: 33 Kecamatan, 12 Kelurahan, 378 Desa, 1.368 Dusun, 3.183 Rukun Warga (RW) dan 14.869 Rukun Tetangga (RT). Pusat pemerintahan kabupaten Malang berada di Kecamatan Kepanjen sebagaimana telah ditetapkan dalam Peraturan Pemerintah Nomor 18 Tahun 2008 tentang Pemindahan Ibu kota Kabupaten Malang dari Wilayah Kota Malang ke Wilayah Kecamatan Kepanjen Kabupaten Malang (RPJMD Kabupaten Malang Tahun 2016 - 2021).

Masyarakat Kabupaten Malang secara demografi, beragam etnis meliputi: Jawa, Tengger, Tionghoa meliputi: agama Islam 96,64\%, agama Kristen 2,33\%, agama Katholik 0,53\%, dan agama Budha 0,09\% (https://id.wikipedia.org/wiki/ Kabupaten_Malang). Jumlah penduduk Kabupaten Malang mulai tahun 2010 - 2020 menurut jenis kelamin (Tabel 1).

Tabel 1. Jumlah Penduduk di Wilayah Kabupaten Malang Berdasarkan Jenis Kelamin 2010 - 2020

\begin{tabular}{|c|c|c|c|c|}
\hline No & Tahun & Lahi-2 & Perempuan & Jumlah \\
\hline 1 & 2010 & 1230594 & 1221403 & 2451997 \\
\hline 2 & 2011 & 1241022 & 1230968 & 2471990 \\
\hline 3 & 2012 & 1250780 & 1240098 & 1240098 \\
\hline 4 & 2013 & 1260414 & 1248284 & 2508698 \\
\hline 5 & 2014 & 2508698 & 1257474 & 2527087 \\
\hline 6 & 2015 & 1278511 & 1265804 & 1265804 \\
\hline 7 & 2016 & 1286867 & 1273808 & 1273808 \\
\hline 8 & 2017 & 1295017 & 1281579 & 2576596 \\
\hline 9 & 2018 & 1302771 & 1289024 & 2591795 \\
\hline 10 & 2019 & 1310100 & 1296104 & 2606204 \\
\hline 11 & 2020 & 1316984 & 1302991 & 2619975 \\
\hline
\end{tabular}

Sumber:https://malangkab.bps.go.id/statictable/2017/05/24/620/jumlah penduduk-menurut-kecamatan-dan-jenis-kelamin-2010 -2020.html 
Jumlah Industri Kecil Menengah (IKM) di Kabupaten Malang sampai tahun 2019 telah mencapai 23.353 industri. Kontribusi sektor industri dan perdagangan terhadap perekonomian Kabupaten Malang terlihat dari komposisi PDRB tahun 1999 di mana sektor industri menyumbang $15,2 \%$ dan perdagangan $22,4 \%$, sehingga berjumlah $37,6 \%$, sedangkan sektor pertanian $35,2 \%$, sektor jasa $12,4 \%$ dan 6 sektor lainnya $14,8 \%$.

Jumlah perusahaan industri akhir tahun 2000 sebesar 18.089 terdiri dari: formal/berijin 583 perusahaan dan informal/rumah tangga 17.506 unit, sedangkan jumlah perusahaan dagang 22.877 terdiri dari formal/berijin 6.815 perusahaan dan informal 16.062. Berdasarkan sumber daya alam dan bahan baku yang tersedia, maka industri agro merupakan industri basis dan dominan di Kabupaten Malang, yaitu $\pm 65 \%$, industri manufaktur $\pm 35 \%$.

Produk IKM logam di Kabupaten Malang, khususnya industri manufaktur $\pm 35 \%$ meliputi: benang, pakaian jadi, spare part mesin, kantong plastik, rak logam, kosmetika, alat kesehatan, ketel dan pipa air, knalpot, sepatu rem, kompor, karoseri/bak mobil, keramik, amplifier, shuttlecock (http://www.malangkab.go.id/site/read/detail/224/in dustri.html).

IKM di bawah pembinaan Disperindag Malang sampai akhir tahun 2018, bidang non agro yang mempunyai tugas pokok dan fungsi membina: industri mesin, alat transportasi, elektronika, telematika, logam, kimia, desain produk dan aneka. Disperindag Kabupaten Malang telah membina sebanyak 23.236 industri terdiri dari: 30 industri besar, 414 industri kecil, 1.487 industri menengah, dan 21.305 industri rumah tangga (abloidjawatimur.com/dibina-disperindag-ikm-

kabupaten-malang-makin-berkembang/).

Indonesia merupakan salah satu negara pengkonsumsi kendaraan bermotor terbanyak di dunia terutama produk sepeda motor. Total jumlah sepeda motor di Indonesia saat ini mencapai separuh total penduduk Indonesia yang artinya setiap dua orang di Indonesia memiliki satu sepeda motor.

Mahalnya harga mobil menjadi salah satu faktor pembelian sepeda motor semakin tinggi, sehingga masyarakat Indonesia lebih memilih yang praktis naik kendaraan sendiri daripada memakai transportasi umum. Mudahnya membeli sepeda motor dengan uang muka kecil bahkan sampai 0\% menyebabkan sepeda motor menjadi tinggi diminati masyarakat Indonesia, sehingga menimbulkan kemacetan di jalan raya dan tingkat kecelakaan pengguna sepeda motor semakin meningkat (Gambar 2).
Tahun 2011 jumlah sepeda motor mencapai 7 juta unit, sedangkan tahun 2018 jumlah sepeda motor mencapai 6,3 juta unit, artinya konsumsi sepeda motor di Indonesia tak kurang dari 6 juta unit setiap tahunnya. Jumlah sepeda motor di Indonesia hingga saat ini sudah mencapai 137,7 juta unit.

Jumlah penduduk Indonesia tahun 2018 mencapai 260 juta dan kepemilikan sepeda motor mencapai 137,7 juta artinya jumlah sepeda motor tersebut, sudah mencapai separuh dari jumlah penduduk Indonesia (https://aripitstop.com /2019/03/13/total-jumlah-motor-di-indonesiamencapai-separoh-total-penduduk-indonesia/).

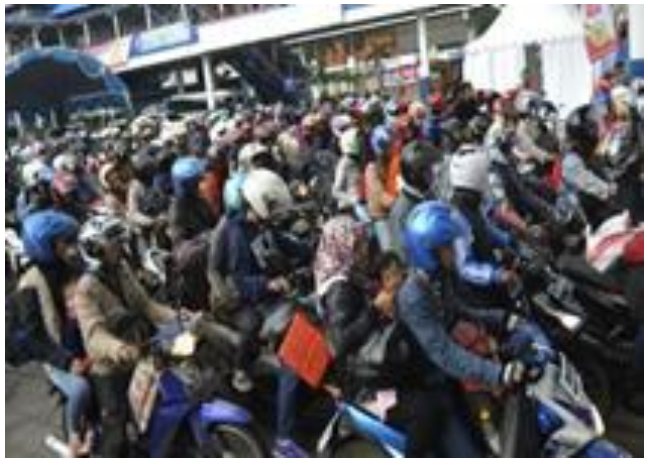

Gambar 2. Masyarakat Pengguna Sepeda Motor

Jumlah sepeda motor yang sangat pesat pertambahannnya berdampak terhadap ketersediaan suku cadang (sparepart) atau komponen mesin di pasaran, sehingga memberi peluang bagi IKM Logam di bawah pembinaan Disperindag tingkat provinsi, kota dan kabupaten, khususnya IKM Logam di Kabupaten Malang untuk mendirikan industri komponen sepeda motor. Komponen mesin sepeda motor yang sering mengalami aus (wear) akibat gesekan (friction) seperti:

1. Rantai rol

Rantai rol (rol chain) merupakan transmisi tak langsung (indirect transmission) yang berfungsi untuk mentransmisikan daya dan putaran yang dibelitkan sekeliling sproket (Gambar 3)

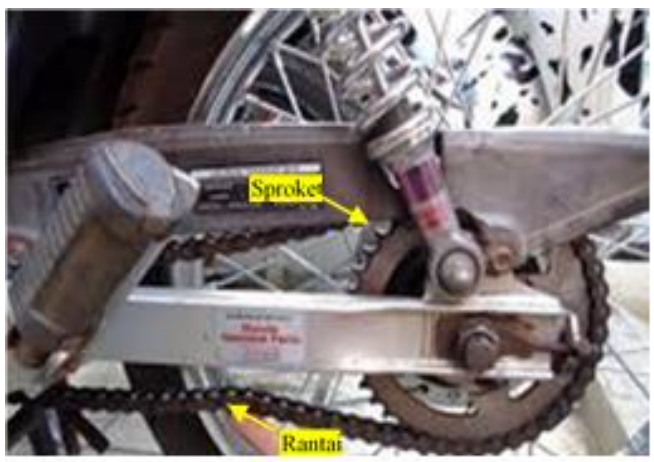

Gambar 3. Rantai - Sproket

Sumber: https://www.otosia.com/tips/merawat-rantai- jangantunggu-sampai-putus.html 
2. Sproket

Sproket (sprocket) merupakan komponen berbentuk roda bergerigi yang berpasangan dengan rantai di mana sproket tidak saling bersinggungan dengan sproket lainnya (Gambar 3).

3. Sepatu rem dan kampas rem

Sepatu rem (shoe brake) dan kampas rem (canvas brake) merupakan komponen yang letaknya menyatu antara sepatu rem dengan kampas rem yang terpasang pada roda dengan permukaan tromol bagian dalam untuk menghasilkan daya pengereman (Gambar 4).

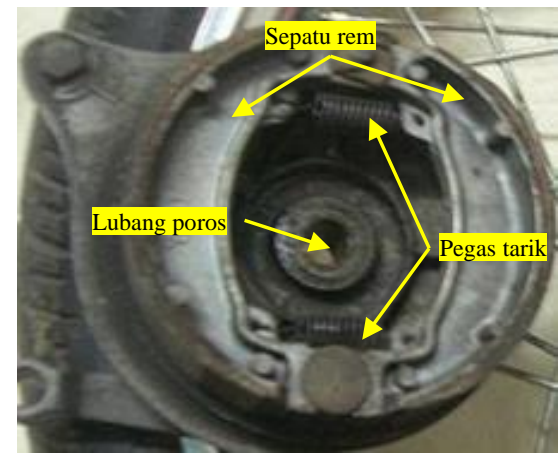

Gambar 4. Sepatu Rem dan Kampas Rem Sepeda Motor Sumber: https://www.otosia.com/berita/dari-drum-brakeistilahnya-jadi-rem-tromol.html

\section{Tromol rem}

Tromol rem (drum brake) merupakan komponen sepeda motor berbentuk mangkuk sebagai media gesekan. Fungsi tromol rem sebagai perantara putaran dari roda, artinya tromol rem akan berputar sesuai putaran roda, sehingga saat tromol rem dihentikan putarannya, otomatis roda sepeda motor akan berhenti berputar (Gambar 5)

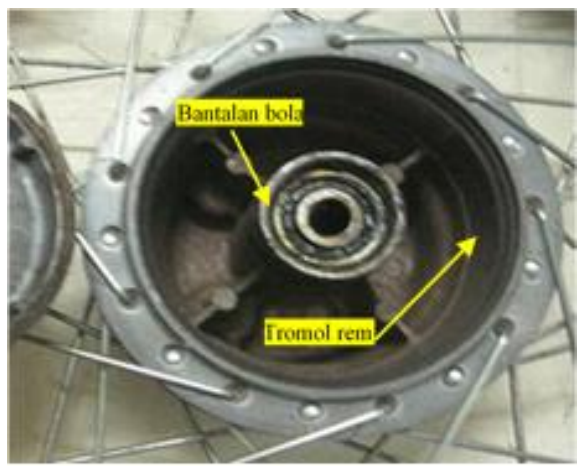

Gambar 5. Tromol Rem Sepeda Motor

Sumber: https://www.otosia.com/berita/dari-drum-brakeistilahnya-jadi-rem-tromol.html

\section{Bantalan Bola}

Bantalan bola (ball bearing) merupakan komponen sepeda motor berfungsi untuk menumpu gandar yang dipasang pada roda depan dan belakang tanpa menimbulkan gesekan yang berlebihan (Gambar 6).

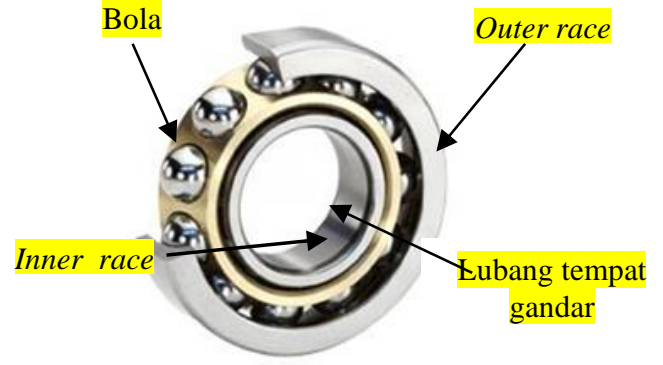

Gambar 6. Bantalan Bola

Sumber: https://www.prorentjakarta.com/cara-mendeteksi-lahermotor-yang-rusak/

\section{b. Pelaksanaan Bimtek bagi IKM Logam Disperindag Kabupaten Malang}

Bimbingan teknis (bimtek) IKM logam merupakan kegiatan yang dilaksanakan oleh Disperindag Kabupaten Malang bekerjasama dengan Jurusan Teknik Mesin Fakultas Teknik Universitas Merdeka Malang. Sebelum pelaksanaan bimtek dimulai, peserta melaksanakan her-registrasi, khususnya bidang industri manufaktur terdiri dari: (1) ketel dan pipa air, (2) knalpot, (3) sepatu rem, (4) kompor, (5) karoseri/bak mobil, (6) keramik, (7) bengkel las teknik (Andrijono, R. D., Sufiyanto, S., 2019) (gambar 7).

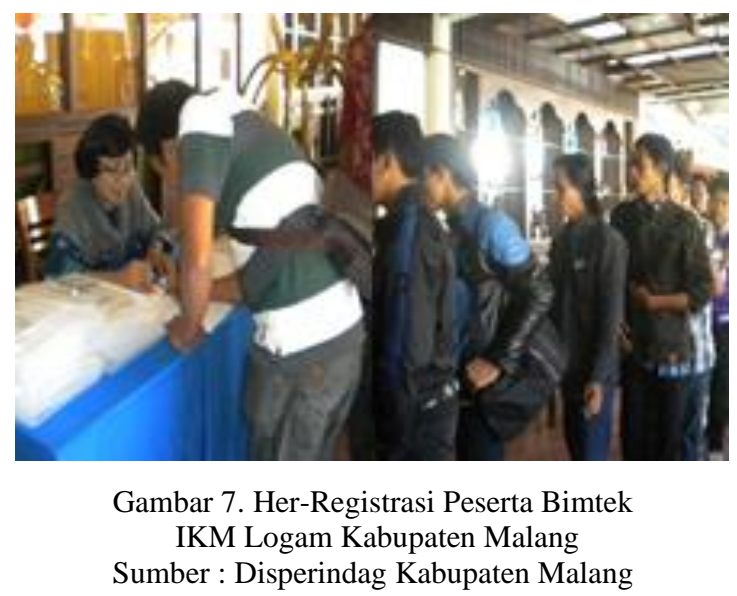

Materi yang diberikan kepada peserta bimtek bersifat kaji teroritis dengan menitik beratkan:

a. Pembuatan sepatu rem sepeda motor dengan proses HPDC (High Pressure Die Casting).

b. Pemilihan logam cor untuk pembuatan sepatu rem sepeda motor.

c. Dapur peleburan dan sistem kontrol temperatur peleburan.

d. Proses penuangan pada cetakan dengan proses HPDC.

e. Sistem kontrol temperatur penuangan logam cor.

f. Proses pembongkaran hasil cor (as-cast) dari cetakan dengan proses HPDC.

g. Proses pengerjaan akhir.

h. Proses control kualitas produk 


\section{METODE KEGIATAN}

Bimtek merupakan kegiatan pengabdian kepada masyarakat bagi dosen sebagai implementasi dari salah satu tri dharma perguruan tinggi untuk membantu permasalahan bagi IKM, khususnya IKM logam Kabupaten Malang. Sebelum bimtek dimulai dilakukan acara pembukaan oleh perwakilan Disperindag Kabupaten Malang (Gambar 8).

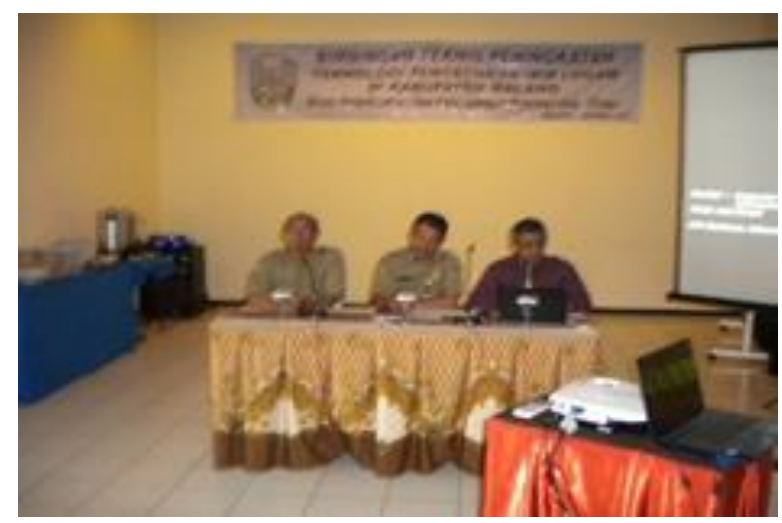

Gambar 8. Acara Pembukaan Bimtek oleh Disperindag Kabupaten Malang

Sumber: Disperindag Kabupaten Malang

Penyampaian materi bimtek menggunakan 2 (dua) metode meliputi: metode ceramah dan metode diskusi.

a. Metode Ceramah

Metode ceramah (preaching method) merupakan metode penyampaian materi bimtek bersifat kognitif kepada peserta bimtek (Gambar 8). Kognitif diartikan potensi intelektual meliputi: pengetahuan (knowledge), pemahaman (comprehention), penerapan (aplication), analisa (analysis), sintesa (sinthesis), evaluasi (evaluation).

Materi bimtek bersifat kognitif meliputi: (a) pembuatan sepatu rem sepeda motor dengan proses HPDC, (b) pemilihan logam cor untuk pembuatan sepatu rem sepeda motor, (c) dapur peleburan dan sistem kontrol temperatur peleburan, (d) proses penuangan pada cetakan dengan proses HPDC, dan (e) sistem kontrol temperatur penuangan logam cor, dan (f) proses pembongkaran hasil cor dari cetakan dengan proses HDPC.

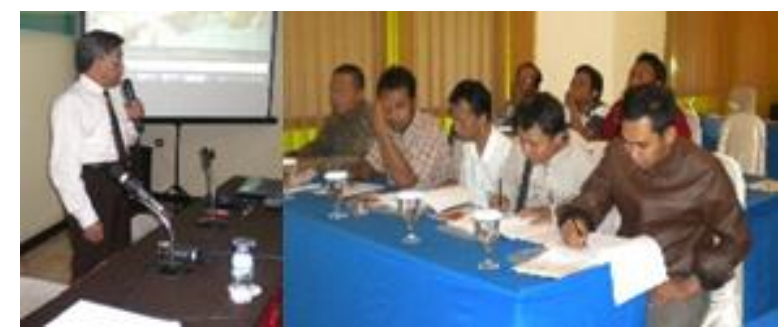

Gambar 8. Metode Ceramah Bersifat Kognitif Sumber: Disperindag Kabupaten Malang b. Metode Diskusi

Metode diskusi (discussion method) merupakan metode yang berhubungannya dengan pemecahan masalah (problem solving). Metode ini lazim disebut sebagai diskusi kelompok (group discussion) dan resitasi bersama (socialized recitation). Metode tersebut, dilakukan setelah selesai penyampaian materi melalui metode ceramah (Gambar 9).

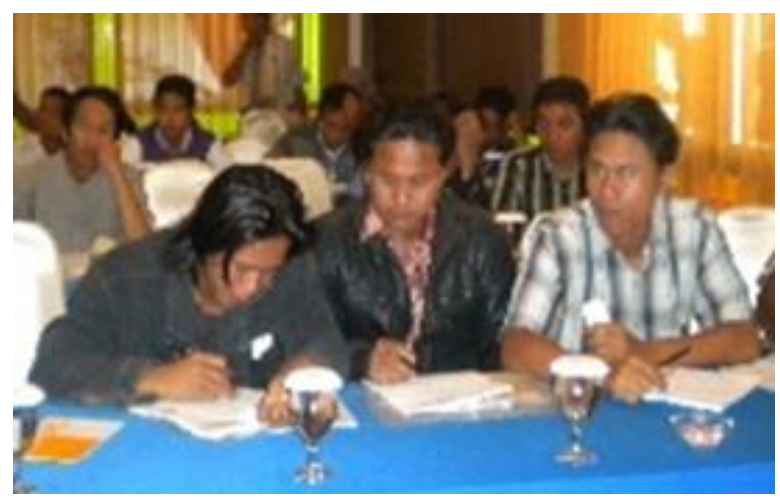

Gambar 9. Metode Diskusi Kelompok Sumber: Disperindag Kabupaten Malang

\section{HASIL DAN PEMBAHASAN}

Pengabdian kepada masyarakat melalui bimtek yang dilaksanakan oleh Jurusan Teknik Mesin Fakultas Teknik Universitas Merdeka Malang merupakan kerjasama dengan Disperindag Kabupaten Malang diharapkan dapat memperoleh pengetahuan teoritis proses pembuatan sepatu rem dengan HDPC menggunakan logam cor jenis skrap aluminium (aluminium scrap) (Gambar 10) dan sifatsifat aluminium (Tabel 2).

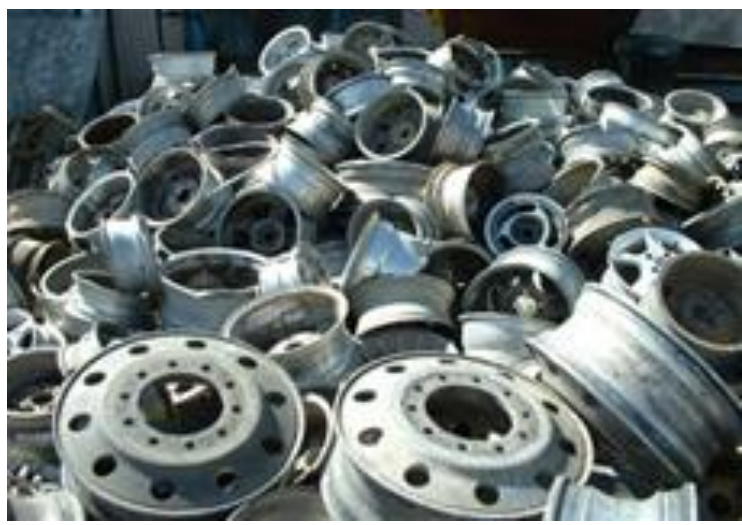

Gambar 10. Skrap Aluminium

Sumber : https://www.ec21.com/product-details/AluminumWheel-Scrap--9754270.html 
Tabel 2. Sifat-Sifat Aluminium

\begin{tabular}{|c|c|c|}
\hline No & Sifat & Keterangan \\
\hline 1 & Titik lebur & Aluminium mempunyai titik lebur $660^{\circ} \mathrm{C}$ \\
\hline 2 & Titik didih & Aluminium mempunyai titik didih $2452{ }^{\circ} \mathrm{C}$ \\
\hline 3 & $\begin{array}{l}\text { Kekuatan } \\
\text { tarik }\end{array}$ & $\begin{array}{l}\text { Aluminium mempunyai kekuatan tarik } 4,76 \\
\mathrm{~kg} / \mathrm{mm}^{2}\end{array}$ \\
\hline 4 & $\begin{array}{l}\text { Anti } \\
\text { magnetis }\end{array}$ & Aluminium adalah logam yang anti magnetis \\
\hline 5 & Ringan & $\begin{array}{llll}\text { Massa jenis } & 2,7 & \mathrm{gram} / \mathrm{cm}^{3} & \text { pada temperatur } \\
\text { kamr } 29^{\circ} \mathrm{C} \text { dan } 2,368 \mathrm{gr} / \mathrm{cm}^{3} & \text { pada } \\
\text { temperatur } 660{ }^{\circ} \mathrm{C} & & & \end{array}$ \\
\hline 6 & Kuat & $\begin{array}{l}\text { Aluminium mempunyai regangan } 8 \mathrm{~kg} / \mathrm{mm}^{3} \text {, } \\
\text { regangan dapat berubah menjadi lebih kuat } \\
\text { dua kali lipat apabila aluminium dilakukan } \\
\text { proses paduan seperti: } \mathrm{Mg}, \mathrm{Zn}, \mathrm{Mn}, \mathrm{Si} \text { atau } \\
\text { proses pengerolan }\end{array}$ \\
\hline 7 & Tahan korosi & $\begin{array}{l}\text { Aluminium mempunyai sifat tahan korosi } \\
\text { karena terdapat lapisan aluminium oksida } \\
\left(\mathrm{Al}_{2} \mathrm{O}_{3}\right) \text { yang tipis dan sangat keras. }\end{array}$ \\
\hline 8 & $\begin{array}{l}\text { Mampu } \\
\text { bentuk }\end{array}$ & $\begin{array}{l}\text { Aluminium mempunyai sifat yang baik untuk } \\
\text { proses mekanik dari kemampuan } \\
\text { perpanjangannya, hal ini dapat dilihat dari } \\
\text { proses penuangan, pemotongan, } \\
\text { pembengkokan, ekstrusi dan penempaan }\end{array}$ \\
\hline 9 & Toksifitas & $\begin{array}{l}\text { Aluminium mempunyai sifat tidak beracun } \\
\text { dan tidak berbau. }\end{array}$ \\
\hline 10 & $\begin{array}{l}\text { Sifat dapat } \\
\text { dipakai } \\
\text { kembali }\end{array}$ & $\begin{array}{l}\text { Aluminium mempunyai titik lebur yang } \\
\text { rendah, sehingga dapat memperoleh kembali } \\
\text { logam Aluminium dari scrap. }\end{array}$ \\
\hline 11 & Nomor atom & 13 \\
\hline 12 & $\begin{array}{l}\text { Massa atom } \\
\text { relatif }\end{array}$ & 26,98 \\
\hline
\end{tabular}

Sumber:Avner, 1987

Pertumbuhan sepeda motor di wilayah Kabupaten Malang (Tabel 2) semakin pesat, maka diperlukan ketersediaan suku cadang salah satunya sepatu rem. Permukaan kampas rem yang menyatu dengan sepatu rem mudah aus akibat gesekan dengan tromol saat dilakukan pengereman. Untuk memenuhi kebutuhan tersebut, perlu Disperindag Kabupaten Malang memberi mendorong bagi IKM Logam untuk mendirikan industri pengecoran logam termasuk penguasaan iptek meliputi: (a) pemilihan jenis logam yang dicor, (b) pemilihan jenis cetakan, (c) pemilihan jenis dapur peleburan, (d) proses melakukan paduan logam, (e) sifat hasil cor, dan (f) kontrol kualitas (Andrijono, R. D., Sufiyanto, S., 2019) khususnya untuk memproduksi sepatu rem dengan memanfaatkan aluminium skrap sebagai bahan baku.

Proses pengecoran (casting process) merupakan salah satu teknologi untuk memproduksi komponen atau suku cadang (sparepart) kendaraan bermotor, kereta rel, kereta barang, barang-barang kerajinan, bangunan sipil, peralatan pertanian, dan peralatan rumah tangga dengan cara mencairkan logam di dalam dapur peleburan kemudian dituang menggunakan ladel (ladle) ke dalam rongga cetak (cavity) yang ada di dalam cetakan dan selanjutnya hasil cor (blank casting) dikeluarkan dari cetakan dengan cara dirusak atau tanpa dirusak tergantung jenis cetakan yang digunakan (Andrijono, R. D., Sufiyanto, S., 2018).
Keuntungan proses pengecoran secara umum meliputi: (a) dapat digunakan untuk proses remelting, (b) mampu memproduksi hasil produk dengan geometri yang rumit dan kompleks, (c) cetakan dapat digunakan berulang-ulang, (d) dapat digunakan untuk produk massal, dan (e) mampu menghasilkan hasil cor dengan ketelitian yang tinggi, sedangkan kerugiannya secara umum meliputi: (a) hasil cor rentan dengan cacat, (b) hasil cor dari hasil proses pengecoran tertentu memerlukan proses pengerjaan lanjut, (c) kurang ekonomis untuk proses produksi dalam jumlah kecil, dan (e) permukaan hasil cor umumnya lebih kasar dibanding hasil proses pemesinan.

Proses pengecoran dapat dilakukan dengan 2 (dua) macam seperti: (a) traditional casting meliputi: pengecoran cetakan pasir basah (green sand mold casting), cetakan pasir kering (dry sand casting), pengecoran cetakan kulit (sheel mold casting), pembentukaan termal vakum (vacuum mold casting), full mold casting dan cement mold casting, (b) non traditional casting meliputi: permanent-mold casting, centrifugal casting, plaster-mold casting, invesment casting), Solid-Ceramic Casting, dan High Pressure Die Casting (Groover, M.P, 2007).

Salah satu material yang digunakan untuk pembuatan sepatu rem dengan memanfaatkan aluminium skrap. Sepatu rem merupakan komponen sepeda motor yang memiliki geometri relatif kompleks, sehingga memerlukan proses pengerjaan dengan ketelitian yang tinggi dan tidak cacat. Pembuatan sepatu rem sepeda motor membutuhkan ketepatan ukuran yang sangat tinggi, sehingga dibutuhkan teknologi proses yang mampu mengurangi proses pengerjaan lanjut (Andrijono, $\mathrm{R}$. D., Sufiyanto, S., 2019).

Salah satu cara untuk memperoleh kebutuhan tersebut, dapat dilakukan dengan proses pengecoran jenis HPDC. HPDC merupakan salah satu jenis dari pengecoran dengan tekanan di mana logam cair dibekukan pada tekanan yang tinggi diantara cetakan (dies) dan hidrolik pada ruang tertutup (Ghomashchi \& Vikrov. 2000). Proses pengecoran HPDC pada dasarnya mengkombinasikan antara proses pengecoran dan proses penempaan (akibat adanya tekanan) (Gambar 11). 


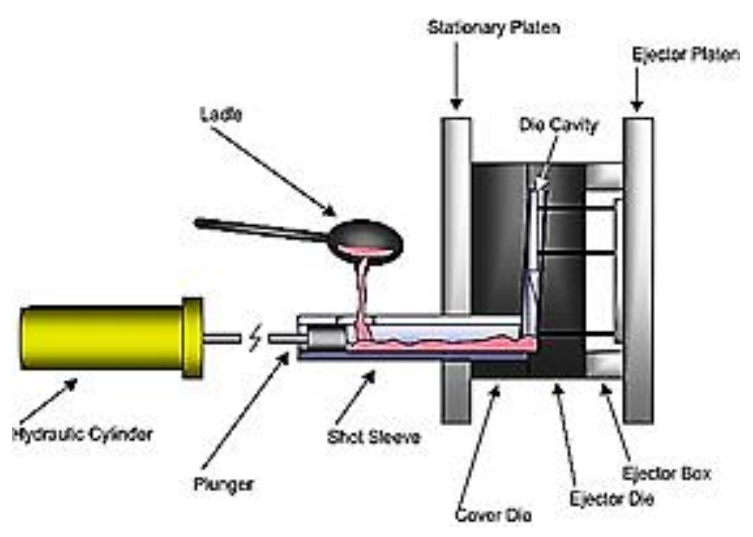

Gambar 11. High Pressure Die Casting

Sumber: Mukesh Kumar Singh, 2016

HPDC dibedakan 2 (dua) macam meliputi: HPDC Cold Chamber digunakan untuk logam dengan temperatur cair tinggi seperti: aluminium dan tembaga serta paduannya dan HPDC hot chamber digunakan untuk logam dengan temperatur cair yang rendah seperti: timah hitam $(\mathrm{Pb})$, timah putih $(\mathrm{Sn})$, seng (Zn). Teknik pembuatan sepatu rem sepeda motor yang digunakan dalam bimtek ini menggunakan HPDC Cold Chamber karena material untuk pembuatan sepatu rem sepeda motor menggunakan aluminium skrap yang memerlukan temperatur cair tinggi (Athanasius Priharyoto Bayuseno, Nasrudin Arif (2011).

Parameter utama proses pengecoran HPDC meliputi: (a) temperatur ruang, (b) temperatur cetakan, (c) tekanan, (d) komposisi logam cair, dan (e) volume logam cairan (Ghomashchi dan Vikrov, 2000). Pengaruh dari masing-masing parameter tersebut, akan mempengaruhi terhadap sifat fisik (physical properties) dan sifat mekanis (mechanical properties) hasil cor seperti: (a) ukuran besar butir (grain size), (b) porositas (porosity), (c) sifat kekerasan (hardness properties), (d) sifat kekuatan tarik (tensile strength properties), dan (e) segregasi (segretation).

Pada proses HPDC, logam cair diinjeksikan dengan tekanan tinggi sampai masuk ke dalam rongga cetakan (cavity). Tekanan yang digunakan di atas 7 Mpa dengan dilengkapi peralatan terdiri dari: dua plat vertikal yang terletak saling berhadapan. Dua plat tersebut, meliputi: fix plate dan moveable plate, sehingga cetakan dapat dibuka dan ditutup untuk mengeluarkan hasil cor (Athanasius Priharyoto Bayuseno, Nasrudin Arif (2011).

\section{KESIMPULAN}

Skrap aluminium merupakan logam dasar untuk pembuatan sepatu rem yang memiliki sifat dapat dilebur kembali dan salah satu cara untuk memperoleh produk sepatu rem secara massal tanpa diperlukan proses pengerjaan lanjut dapat menggunakan proses pengecoran HDPC yang memiliki tingkat kepresisian yang tinggi dan proses pencetakannya dapat dilakukan secara berulangulang dengan bentuk serta ukuran hasil cor yang sama.

\section{DAFTAR PUSTAKA}

abloidjawatimur.com/dibina-disperindag-ikmkabupaten-malang-makin-berkembang

Andrijono, R. D., Sufiyanto, S., (2018), Bimtek Mutu Produk Cor Baling-Baling Kapal Nelayan Hasil Cetakan Pasir Dengan Bahan Dasar Skrap Aluminium Bagi IKM Disperindag Kota Pasuruan, Abdimas, Vol. 3 No. 2, Hal. 24-32, Universitas Merdeka Malang

Andrijono, R. D., Sufiyanto, S., (2019), IbM Bengkel Las Teknik Dalam Upaya Peningkatan Kualitas Rectangular Pipe Bending Process Dengan Desain Flexible Roll, Prosiding Senadimas, September 2019, Hal. 106-114, Universitas Slamert Riyadi

Athanasius Priharyoto Bayuseno, Nasrudin Arif (2011) ISSN (ONLINE): 2250-0758, ISSN (PRINT): 2394-6962 Chamdani 2011, Jurnal Rotasi ADC 12 Sebagai Material Sepatu Rem Menggunakan Pengecoran High Pressure Die Casting denganVariasi Temperatur Penuangan. Volume 13, Nomor 1 Januari 2011, halaman 1723 Jurusan Teknik Mesin Universitas Diponegoro.

Avner Sidney H. 1987. Introduction to Physical Metallurgy, Singapore: McGraw-Hill Book Company.

Dinas Pendapatan Provinsi Jawa Timur UPT Malang Utara dan Dinas Pendapatan Provinsi Jawa Timur UPT Malang Selatan

Ghomashchi \& Vikrov (2000). "High Pressure Die Casting".

Groover Mikell. P. 2007. Fundamentals of Modern Manufacturing. John Wiley \& Sons, INC.

https://aripitstop.com/2019/03/13/total-jumlahmotor-di-indonesia-mencapai-separoh-totalpenduduk-indonesia

https://id.wikipedia.org/wiki/Kabupaten_Malang https://malangkab.bps.go.id/statictable/2017/05/24/6 20/jumlah penduduk-menurut-kecamatan-danjenis-kelamin-2010 -2020.html

https://www.ec21.com/product-details/AluminumWheel-Scrap--9754270.html 
https://www.otosia.com/berita/dari-drum-brakeistilahnya-jadi-rem-tromol.html

https://www.otosia.com/berita/dari-drum-brakeistilahnya-jadi-rem-tromol.html

https://www.otosia.com/tips/merawat-rantaijangan-tunggu-sampai-putus.html

https://www.prorentjakarta.com/cara-mendeteksilaher-motor-yang-rusak/

https://www.prorentjakarta.com/cara-mendeteksilaher-motor-yang-rusak/

Mukesh Kumar Singh (2016), Manufacturing and Design of Single Cavity Pressure Die Casting Die with CAD/CAM Department of Mechanical Engineering, Vindya Institute of Technology and Science, Satna (M.P.), IND Volume-6, Issue-4, July-August 2016 International Journal of Engineering and Management Research Page Number: 262-273 ISSN (ONLINE): 2250-0758, ISSN (PRINT): 2394-6962

RPJMD Kabupaten Malang Tahun 2016 - 2021

shuttlecock(http://www.malangkab.go.id/site/read/de tail/224/industri.html 